International Journal of Linguistics, Literature and Translation

ISSN: 2617-0299 (Online); ISSN: 2708-0099 (Print)

DOI: $10.32996 / \mathrm{ijllt}$

Journal Homepage: www.al-kindipublisher.com/index.php/ijltt

IJLLT

\title{
Experimental Narrative Structure and the Advent of New Humanism in Cormac McCarthy's The Road
}

\author{
Abdalhadi Nimer Abdalqader Abu Jweid ${ }^{1} \square$ and Omar Abdullah Al-HajEid ${ }^{\mathbf{2}}$ \\ ${ }^{1}$ Assistant Professor of English Literature, Faculty of Educational Sciences and Arts, UNRWA, Jordan \\ ${ }^{2}$ Assistant Professor of Linguistics, Faculty of Educational Sciences and Arts, UNRWA, Jordan \\ $\square$ Corresponding Author: Abdalhadi Nimer Abdalqader Abu Jweid, E-mail: A.ABUJWEID@UNRWA.ORG
}

\begin{tabular}{ll}
\hline ARTICLE INFORMATION ABSTRACT \\
\hline
\end{tabular}

Received: 06 October 2021

Accepted: 22 November 2021

Published: 16 December 2021

DOI: 10.32996/ijllt.2021.4.12.11

\section{KEYWORDS}

Environment, Experimentation,

McCarthy, Narratology, New

Humanism, Post-apocalypse, Post-

modernism
This paper attempts to study the experimental narrative structure to explore postmodern new humanism in Cormac McCarthy's The Road. The study focuses on three inextricable narrative elements: the characters, narrative descriptions, and the novel's spatial setting. It will demonstrate how McCarthy's uses postmodern narrative experimentation to accentuate the necessity of halting the danger lurking behind the sustainable safety of the natural environment. Therefore, the study first examines the nameless characters of the novels as an exemplification of people who are devoid of their identity and sense of belonging due to natural catastrophes. Second, it identifies the narrative descriptions of the devastated environment ensuing gigantic disasters that obliterate the vast majority of the human civilisation. Third, it looks into the conditions of the remaining survivors as the embodiment of the remains of the human civilisation, and these survivors will be explored as the literary paradigm of new humanism living in a post-apocalyptic society leading a new primitive life from scratch. In this sense, the study gaps lie in exploring such new humanism as an archetype of postmodern civilisation surviving the destructive events and their related ethical dilemmas. As such, the study applies a qualitative methodology by following a textual analysis of the novel's characters, narrative descriptions, and spatial setting. Here, narratology will be applied as the theoretical background for interpreting these elements with regard to the post-apocalypse and its new humanistic insights. Thus, the study's main results are the exploration of the novel's apocalyptic events as narrative paradigms of new humanism and McCarthy's use of postmodern experimental narrative structure.

\section{Introduction}

Post-apocalyptic fiction includes a wide variety of imagined settings within specific cultural contexts. It indicates the nature of the future as a horizon of the disaster which might tragically lead to the end of, for example, the human race and the destruction of the environment. The narrative implications of such fiction encompass conceivable speculative scenarios depicted in the literary details of the plot and its thematic aspects. The typical feature of post-apocalyptic fiction comprises the pedantic authorial use of narrative descriptions that make the reader profoundly familiar with the imminent disastrous events; hence, these events might be avoided to guarantee the safety and sustainable development of human lives. The core notion of post apocalyptic fiction, argues Mark Pyne (2021), is the world's perception after the destruction of human lives when it undergoes radical changes after the civilisation's destruction. In this sense, the survivors summon their experience during catastrophic events; and they start "doing their best to get by on a planet ravaged by pollution, consumerism, and reckless resource extraction" (p.1). Therefore, the relationship between post-apocalyptic themes and literature is realistic since this kind of fiction deals with intricate matters that result in drastic changes in the history of humanity.

The problematic nature of post-apocalyptic fiction relates to the use of science for improving human lives, but, in fact, it is harnessed for negative purposes, such as nuclear weapons and mass destruction arsenal that hasten the destruction of the

Copyright: (c) 2021 the Author(s). This article is an open access article distributed under the terms and conditions of the Creative Commons Attribution (CC-BY) 4.0 license (https://creativecommons.org/licenses/by/4.0/). Published by Al-Kindi Centre for Research and Development, London, United Kingdom. 
environment. Being so, the contradictory logic of post-apocalyptic fiction involves the celebration of advanced technology and the feeling of anxiety as a response to technology's unknown bad effect upon life and nature. As such, the authors project such contradiction in the narrative tone to accentuate its authentic danger and the proper way for curbing it via elevating the reader consciousness. This is due to the fact that the apocalyptic peculiarities of this fiction provide the reader with crucial events which change the human view of the world: "crucial and provocative after the apocalypse sets out new principles to guide the once-butno-longer sole superpower as it navigates a transformed world" (Bacevich, 2021, p.13). The projection of these provocative insights within the broad context of post-apocalyptic fiction represents the authorial concerns with the necessity of finding viable solutions to the futuristic problems regarding the continuation of human lives. In this manner, post-apocalyptic fiction unravels the rapid increase of the intimidating feeling of forthcoming extinction events. Consequently, this feeling leads to the emergence of a haunting compulsive return to the devastating scenes of the end of life repressed in the collective human psyche. In this study, my focus will be on the experimental narrative structure to exemplify a new humanism in Cormac McCarthy's The Road, published in 2006. It will reveal McCarthy's depiction of post-apocalyptic events as literary representations of a postmodern new humanism. Thus, narratology will be the primary theoretical background for discussing the selected novel and how it subtlety deals with postapocalyptic themes under literary experimentation.

\section{Literature Review}

McCarthy's The Road is tackled from different critical and thematic perspectives. Mădălina Kimak (2019) approaches the novel by applying post-structuralism. Kimak (2019) scrutinises the novel's narrative components in order to explore McCarthy's subjective philosophy of childhood. The novel abounds with narrative clues necessary for grasping the mature growth of the characters that experience drastic changes during their social development. Kimak (2019) contends that McCarthy has a special view of the role of childhood in the face of the reality that controls and shapes the traits of their gradual maturity. The study sheds light on meticulous literary details that reflect the essence of the plot's discursive elaboration of childhood. In this respect, Kimak (2019) applies Jacques Derrida's concept of logocentrism to discover the role of fathers in creating the personality of their children. The novel hinges on a father and his boy. Being so, the father exemplifies the notion of logocentrism since he instills the principles of morality in his boy who embodies humanity which is in progressive maturity; the plot "in The Road both," argues Kimak (2019), "the father and the boy are humane and can be seen as 'the good guys,' there is a very subtle difference between the two, which helps in deconstructing the logocentric system of the father. The father constructs his discourse around the issue of morality and even though he does want to protect the child whom he regards as the very essence of humanity" (p.35). Kimak (2019) concludes that McCarthy's conceptualisation of childhood greatly depends on the father, who incarnates the idea of human maturity conveyed through codes of morality and good principles.

The works of Carmen Bueno (2019) studies McCarthy's The Road by applying psychoanalysis. The main focus of the study is on the traumatic experience of the novel's catastrophic events. Furthermore, the study sheds light on the existential messages embedded in the course of the fictional incidents. Strikingly, Bueno (2019) contends that McCarthy uses erudite literary expressions that might be deciphered as prophesying indications of military mass destruction. In this sense, the novels hold implied allusions to the world's possible future. By comparing the novel to the literature of 11/9, Bueno (2019) contends that its message lies in its "preapocalyptic" references to what might lead to the destruction and devastation of the whole world; Bueno (2019) writes: "the novel's strength lies in both the portrayal of the emotional consequences of a collective trauma and the existentialist message that it conveys in the face of devastation, while also offering reverberations of our (pre-apocalyptic) times [brackets in original]" (p.72). Consequently, the novel's exceptional significance entails McCarthy's pedantic selection of cogent narrative overtones to highlight the imminent peril of destruction initiated by destructive human practices. Bueno's (2019) study finds that their traumatic reactions shape the emotional response of the novel's characters as they undergo terrifying experiences. She (2019) concludes that the novels bear conscientious connotations to hamper military destruction as the world is getting into an existential nihilistic vicious circle; whereby human beings may not be able to get rid of their living dilemmas.

The study by Gabriella Blasi (2014) illustrates the discursive allegorical peculiarities of McCarthy's The Road. Like Bueno (2019), Blasi (2014) analyses the narrative components of the novel in order to explore McCarthy's treatment of the futuristic destiny of humanity. However, Blasi (2014) departs from Bueno's (2019) study by applying eco-criticism to demonstrate the mutual relationship between human beings and their environmental nature. In this regard, Blasi (2014) specifically approaches the novel's language because it employs allegorical descriptions that function as a way of decoding. McCarthy emphasises preserving the environmental nature because it is necessary for the continuation of the human civilisations and transcendence: "in McCarthy's novel human transcendence through nature is precluded" (p.92). The novel provides viable alternatives for delaying the decomposition of the human civilisation as it abounds with fictional events perceived by the reader by virtue of understating the importance of searching for peaceful redemption. Moreover, McCarthy's literary savvy embellishes the plot with allegorical details that furnish the novel's ecological nuances; Blasi (2014) comments: "in such an allegorical way of seeing, death is accepted as pervading nature. Allegorically, nature is death's face, an image already in decomposition that evades any transcendence. Thus, the allegorical way of seeing precludes redemption of worldly things and confronts the reader with finitude" (p.92). McCarthy's 
perfect use of allegorical language, according to Blasi (2014), underpins the integral role of the environmental nature for people through impressively describing nature appealing to the reader's corresponding awareness of the novel ecological context. Thus, the major finding of Blasi's (2014) study is McCarthy's innovative imagination of creating allegorical anthropocentric cosmic order at the time of ecological chaos, which threatens the material reality of humanity's environmental impeccable milieus.

My study, however, will differ from the aforementioned studies by discussing the narrative structure of McCarthy's The Road. Unlike these studies, my study will shed light on three narrative elements that are hardly tackled in the previous scholarship on the selected novel. Consequently, my point of departure will focus on the characters, narrative descriptions, and the spatial setting of the novel. In this regard, the interpretation of these elements will be reinforced by applying narratology as the theoretical background, which is scarcely tackled in the previous studies. For this reason, my study's methodology will be both textual and contextual. As for the textual analysis will pinpoint the characters, narrative descriptions, and the spatial setting of the novel within the scope of literary experimentation. These elements will be discursively interpreted as interrelated components that lay bare the fundamental basis of the study's contextual analysis. The topics of the contextual analysis will be limited to the thematic aspects of postmodern new humanism and its depiction via post-apocalyptic events created by McCarthy's deft use of narrative experimentation in the novel, which is almost left incompletely tackled in the previous studies.

\section{Analysis and Discussion}

McCarthy's The Road is mainly about the post-apocalypse, which has recurring diverse themes, especially in postmodern literature. The novel's portrayal of post-apocalyptic life is attributed to the fictional scenes of survivors of overwhelming destruction that results in the utter annihilation of human civilisation described in the initial parts of the plot. The novel hinges on the story of a father accompanying his son as they decide to leave their residence to the south seeking refuge from a mysterious and unknown catastrophic disaster that struck the entire world. The novel introduces the father and his son without names, i.e., they are just introduced as a father and a son undergoing harsh experiences when they leave for the south through extremely rough terrains. Throughout their escape journey, they meet bitter conditions and uncanny encounters, such as devastating landscapes as a result of huge fires, deserted houses, abandoned towns, and rotting corpses. This is undoubtedly caused by the calamitous disaster that overwhelmed human civilisation and negatively affected its status. The father and the son are among very few survivors who remained alive after the occurrence of this catastrophic event because the other people were killed by rape, cannibalism, or murderous attacks during the catastrophe.

They could hardly survive in such difficult weather, and they only depended on some food, shelter, and few ration supplies. For this reason, they intentionally become cautious and vigilant of the other survivors whom they may encounter on the way. That is, they might be prone to theft or murder by these survivors who also seek food to save their lives. Consequently, they maintain their fortitude in the face of this challenge; and they show great mastery of determination and stamina to be good people by promising not to harm other survivors regardless of their unknown destiny. Specifically, the boy reveals his great love for humanity, and he expresses his stout will to save humanity and in these catastrophic conditions. He hopes to achieve this humanitarian love by emphasising his readiness to help and support the victims and the remnants of the catastrophe wherever he finds them.

The father and the boy proceed their journey southward. They hardly could withstand the journey due to the nature of the terrains that hinder their power and progress. To their disappointment, the father develops bad health problems; and when they reach the limits of the ocean, the father's approaches. They take few rest pauses as they continue their slow progress every day, but the father's health worsens when he begins to cough, spitting blood. They rest in the woods in the middle of one night, and the father dies lying beside his son. Out of grief, the son decides to stay for several days next to his father's dead body till he meets a good family that asks him to join them as a member. The head of this family comes closer to the boy with his wife, son, and daughter. At this stage, the novel ends when the boy feels that it is time to bid farewell to his father and embark on a different experience under the protection and care of the new family.

McCarthy's The Road employs dexterous features of the characters. It parades them in a strange situation that worsens their lives and prevents them from remaining safe and peaceful. This is because McCarthy's uses exceptional narrative peculiarity via the experimental depiction of their post-apocalyptic natural milieus. According to Andrew Radford and Hannah Van Hove (2021), the narrative aspects of such post-apocalyptic are appropriated using precise descriptive details that are necessary for grasping the entire post-apocalyptic scene. Being so, the characters undergo radical change since they used to live in a perfect natural environment. However, they are no longer blessed with such living as they survived tremendous natural destruction. Therefore, the narratological criteria for scrutinising the experimental characters relate to the contradictory living conditions of after the occurrence of huge environmental destruction; and, in this respect, Radford and Hannah Van Hove (2021) argue that experimental literary characters "make place indistinguishable, obliterating detail; the individual character of cities and landscapes is wiped out, the achievements of humanity and the diversity of nature eradicated" (p.168). Scenes of survival in this catastrophic event shed light on the characters that are prone to annihilating mass destruction. They attempt to find and exit and safe place from this catastrophe by seeking refuge in other places. As a result, they leave their previous residence regions in order to cope with their 
life in the new places. In this manner, the literary significance of the experimental characters lies in their capacity to adapt to new conditions which they never experienced. Strikingly, this radical transformation of the characters' lives signifies the notion of a new humanism that includes the lives of individuals or groups of people in severely apocalyptic destruction.

McCarthy, in The Road, conveys such experience through the father and the son's experience. They could find new living after the massive apocalyptic events. Notwithstanding, he meticulously depicts the post-apocalyptic destruction at the novel's end. The scene described in the quotation below exemplifies the entire devastation of the environmental nature that forces the characters to leave their homes. In doing so, McCarthy relies on his characters as a literary demonstration of environmental decadence. He uses the narrative descriptions as vital indications of how this decadence embodies the characters' lives' turning point. The father and the son, who survived the catastrophe, depart for a new life though they underwent difficult experiences. Yet, McCarthy recounts their experience in order to pave the way for portraying their new life as a post-apocalyptic scenario; the following scene abounds with apocalyptic mass destruction:

The road crossed a dried slough where pipes of ice stood out of the frozen mud like formations in a cave. The remains of an old were fire by the side of the road. Beyond that, a long concrete causeway. A dead swamp. Dead trees standing out of the grey water trailing gray and relic hagmoss. The silky spills of ash against the curbing. He stood leaning on the gritty concrete rail. Perhaps in the world's destruction, it would be possible at last to see how it was made. Oceans, mountains. The ponderous counter spectacle of things ceasing to be. The sweeping waste, hydroptic and coldly secular. The silence. (p.145)

The description of the deteriorating natural environment in this way reflects McCarthy's obsession with narrative details needed for conveying the panoramic conditions of the characters' post-apocalyptic experience. Although they survived the destruction, they could find suitable and safe places in nature, especially the woods. This is because they have a resting breakthrough in their journey motivated by the hope of living the rest of their life in good natural places. In this respect, Joseph Black (2021) discusses the relationship between the narrative insights of apocalyptic events and the evolution of the characters in fictional works. In the first place, the use of narrative descriptions is of utmost importance for comprehending the authorial portrayal of the apocalyptic events projected in the plot sequence. Furthermore, Black (2021) traces the historical background of the apocalyptic environmental narratives and their close affinity with the formation of the main characters; and literary experimentation with such historical background serves as "a self-referential examination of environmental apocalypse in which characters and events recur throughout history" (p.1779). Consequently, the literary experimental with the depiction of the central characters is reinforced by the authorial symbolic use of these characters' transformations into new lives. For this reason, Black (2021) accentuates the importance of thinking about this experimental narrative formation of the characters in order to understand the core of the whole plot through which the author is able to "create experimental narratives that ask us to rethink what we think we know and understand" (p.1779). Here, the literary experimentation with the central characters is very necessary for deducing the inherent meaning of apocalyptic events and their role in shaping the new stage, i.e., the post-apocalyptic life per se. The narrative scenes of apocalyptic events are closely associated with nature and how it gets destroyed by devastating harm since "apocalyptic fiction and movies have reiterated the same sentiment of fear and unease" (Kundu and Sarkar, 2021, p.8). Moreover, the characters' transformation largely depends on their struggle with a critical incident that left their apparent impact upon their personality and spiritual stamina as they authentically live in apocalyptic ordeals.

McCarthy's The Road is abundant with these apocalyptic ordeals as it deals with the experience of a father and his son who struggle with nature in its worst conditions. At first, they only think of surviving tactics to escape being severely harmed by the apocalyptic events surrounding them. They strongly believe that they will not be safe from environmental destruction due to the surrounding sequences of ten natural catastrophes. In this case, McCarthy does not give them names. This might presumably indicate his universal implication of the boy and father as literary stereotypes of all humanity that would fall victim to forthcoming natural destruction in the future. As such, he implicitly expresses the future of humanity by depicting the experience of these two characters that play a decisive role throughout the plot. Accordingly, he would insert an implied message about the use of mass destruction weapons highly used by the contemporary world's military arsenal since the advent of post-modernism. McCarthy connects this idea with the state of the father and his son after the catastrophe. They leave their home and go astray. They did not find food and shelter except sleeping in the wilderness where no sign of humanity could rescue them. Therefore, they could hardly survive the bitter conditions as they would die of starvation and lack of rations: "they squatted in the road and ate cold rice and cold beans that they'd cooked days ago-already beginning to ferment. No place was to make a fire that would not be seen. They slept huddled together in the rank quilts in the dark and the cold. He held the boy close to him" (p.17). McCarthy's accentuation of these scenes is of paramount importance for two reasons. First, it reflects the real and true conditions of the characters before and at the time of the catastrophic apocalypse. Second, it is necessary to understand their change when they continue their journey to seek safe refuge from imminent death. In this case, they could get rid of their previous negative experience during the catastrophe and embark on a new life with the family they found in the woods. To the boy's disappointment, his father dies before they can 
enjoy the new safe living. ${ }^{2}$ Nevertheless, McCarthy depicts the boy's deprivation of this life at the beginning of the novel, overwhelmed by fear and loss. The boy feels scared, but the father assures him that it was just an earthquake and they will be all right soon:

We should go, Papa. Can we go?

Yes. We can go.

I'm scared.

I know. I'm sorry.

I'm really scared.

It's all right. We shouldn't have come.

$\cdots$

It was an earthquake. It's gone now. We're all right. Shh. (p.16)

The boy and the father represent McCarthy's narrative description of the cause of environmental destruction, namely, the earthquake and its aftermath. This event embodies the drastic change of the characters, especially when they decide to leave their dwelling places out of their fear of other negative sequences of the earthquake. McCarthy, here, unravels this change by virtue of literary experimentation, denoting their departure to a new life that is completely different from their lives before the earthquake. Furthermore, he experiments on the novel's environmental spatial setting as a way of revealing the characters' progressive journey to a new life. They could not achieve their journey until they guaranteed a new good living away from disturbing natural destruction. They pursue their happiness through living in the woods. Yet, the father's death intensifies the boy's misery because the father was the source of his safety.

McCarthy experiments with his characters by connecting them with the environmental places described in the plot. As a matter of fact, these places represent the spatial setting of the novel. It includes several narrative descriptions relating to the physical elements of nature that serve as a stable living place for the major characters. However, these characters' lack stability as they are intimidated by apocalyptic incidents, i.e., earthquakes. Spatial settings function as regional circumferences dwelt by human beings who interact with each other within a specific place. Gary Westfahl (2021) offers a discursive explanation of the fictional places representing the ideal dwelling regions for the characters. Furthermore, these places are close to the literary nuances of postapocalyptic narrative as they involve intricate relationships between human beings endangered by the destruction of these places. In this sense, the settings of post-apocalyptic writings comprise "novels involved journeys through a post-apocalyptic Earth with familiar elements" that the author creates by virtue of "imaginatively developed settings" (p.224). Westfahl (2021) refers to the natural components, such as regions, fauna, and flora, as integral and coherent elements providing humanity with a safe and peaceful environment. However, these components disappear by the devastating power of the natural apocalypse. In this regard, the survivors attempt to live in places untouched or destroyed by such apocalyptic events.

In McCarthy's The Road, the woods are the central post-apocalyptic environmental setting for humanity. The boy and his father, who are literary miniatures of humanity as a whole, decide to stay in the woods despite the tragic sequences of the earthquake. Many scenes are set in the woods, where they embark on a new journey. They chose the woods for their safety as soon as the earthquake occurred. Though they believe that the earthquake had destroyed the entire world, they become pleased with the woods as a perfect place for their survivals: "they ate a can of white beans, passing it between them, and he threw the empty tin into the woods. Then they set out down the road again" (p.37). In this way, the woods embody the beginning of post-apocalyptic life, leading to peace and stability, which they almost missed during the earthquake. The woods, in this context, incarnate the characters' tendency to avoid any harm as they previously experienced a destructive earthquake. They need to be safe from any other apocalyptic events, learning the importance of departing to a new peaceful life. McCarthy uses the woods as a plain indication of the safe post-apocalyptic setting by joining together the characters and the woods. He experiments with these narrative elements to shed light on the food eaten by the boy and the father as the first sign of new life after a daunting apocalyptic experience. This is true to the boy's predilection to live with the family in the woods at the end of the plot.

The spatial setting, in this case, is a manifestation of regional places that serve as literary replicas of the real places affected by apocalyptic destruction. Literarily, these places include some people show struggle to gain their good living away from this destruction. As such, the places are sorely significant since they enable these people to survive in very harsh conditions. They also enhance the characters to withstand difficult situations because they need to resort to new safe places. Experimental authors,

\footnotetext{
${ }^{2}$ The boy's new life with the family will be later elaborated discursively in the discussion of post-modern new humanism.
} 
therefore, depict young characters in these situations; and such characters pay strenuous effort to survive in their new postapocalyptic life. Being so, authors have tended to create young characters through a literary work that "features a youth who struggles to survive in a post-apocalyptic world" (Westfahl, 2021, p.478). Furthermore, the young characters undergo a bitter experience of fear that provokes their horror and frightening feelings. This is due to the fact that they used to live in the safe conditions of the external world, or as Alice Levick (2021) puts it simply, experimental characters, in post-apocalyptic contexts, have "apocalyptic fears of the potential horror which had previously been limited to the outside world" (p.152). Here, the experimental characters are relatively young; and they embody the authorial selection of post-apocalyptic settings that incite their fear and instability. In this sense, these characters are precisely and intentionally selected for the sake of empowering the author's utilisation of threatened natural places after the occurrence of apocalyptic incidents.

The protagonist of McCarthy's The Road is a boy who is deeply exhausted by the long and daunting journey after the earthquake. Strikingly, McCarthy uses a young protagonist who embarks on this worsening journey, especially when they reach the woods. Though the woods are a source of their rest and peace, it does not offer them complete shelter. The boy plays an integral role by helping his father to survive though the latter is about to die of their negative conditions. McCarthy uses blatant narrative descriptions of these conditions when he portrays the experience of the boy and his father that is overwhelmed by fear and starvation: "he looked like something out of a death camp. Starved, exhausted, sick with fear. He leaned and kissed him and got up and walked out to the edge of the woods and then he walked the perimeter round to see if they were safe" (p.62). In these conditions, McCarthy's narrative descriptions demonstrate his obsession with the negative effect of apocalyptic disasters, which obliterate the basic living conditions of the characters. As an experimental writer, he uses a young literary character to project his authorial insights on how the novel seriously approaches the issue of the environmental apocalypse and its destructive sequences. Again, McCarthy's employment of this personality in the light of apocalyptic threatened settings indicates his literary experimentation.

The experimental literary settings designate the imminent eta danger lurking behind the future of the safe environment. In addition, it predicts the catastrophic conditions of the characters Tereza Dědinová et al. (2021) tackle the discursive peculiarities of the apocalyptic literary settings. They (2021) contend that the apocalyptic settings merely exemplify how nature retards as an apocalyptic event destroys it. In this manner, fictional settings are used by authorial narrative destruction to shed light on the destruction of the Earth that is the mother of people's safety. Dědinová et al. (2021) comment: "the very real destruction and changes the Earth is undergoing due to human activity, we turn more to fiction ... The post-apocalyptic narrative allows us to engage with the crushing imminence of Earth's destruction from a safe space" (p.126). According to Dédinová et al. (2021), the safe space is the core fact of the post-apocalyptic experience. To clarify, the literary characters could obtain their safety by living in a safe place despite its negative conditions. In other words, the safe place is a suitable and perfect refuge for the characters; and the authors rely on certain narrative techniques to accentuate the function of the fictional settings in their works. To relate this claim to literary experimentation, Marco Caracciolo et al. (2022) maintain that the authors depend on their narrative peculiarities to pinpoint the vitality of the setting in casting a lasting impression upon the reader's reception of the endangered setting. By the same token, authors formulate "specific narrative strategies" in the main events of their fictional plots "to portray their setting as a post-human space which poses a serious threat to survivors" (p.105). Caracciolo et al. (2022) argue that the use of the experimental setting is of utmost significance as it enables the authors to comment and reveal the very nature of the characters' lives after the end of an apocalyptic incident. My profound concern, here, perceives the argument of Caracciolo et al. (2022) regarding the "post-human space" that is greatly needed to understand the typical features of the characters' post-apocalyptic life. Moreover, this argument is necessary to deduce the narrative paradigms concerning the characters' permanent life when they find new life opportunities to be safe and peaceful.

McCarthy's The Road reveals life opportunities after the advent of apocalyptic mass destruction. McCarthy provides a vivid picture of how the boy and his father could survive. They had experienced a very bad condition that devastated many people's lives. The novel obviously unravels the destruction that overreached the Earth's entire place. The narrative scenes show how the houses, trees, roads, and other signs of human civilisations are shattered by the apocalyptic destruction. In this context, the boy and his father find their life opportunities by escaping this massive destruction. They left their shattered place and resorted to safer places. Scenes of rubbles and environmental deterioration provoke a sense of fear and intimidation. As the earthquake occurs, it does not leave any track signifying the previous life on Earth. However, the boy and his father could find life among the rubbles of the previous civilisation, which reflects McCarthy's precise depiction of this catastrophe that is described as follows:

They'd begun to come upon dead windfalls of pine trees, great swaths of ruin cut through the countryside. The wreckage of buildings strewn over the landscape and skeins of wire from the roadside poles garbled like knitting. The road was littered with debris, and it was working on getting the cart through. Finally, they just sat by the side of the road and stared at what was before them. Roofs of houses, the trunks of trees. A boat. The open sky beyond where the sullen sea lagged and shifted in the distance. (p.145) 
McCarthy's description of this massive destruction represents the novel's use of experimental narrative strategy, creating a setting featuring the notion of "post-human space" elaborated by Caracciolo et al. (2022). In this regard, I tend to argue that this posthuman space is the parallel embodiment of new humanism representing postmodern civilisation. New humanism is, presumably, achieved by finding survival and family. Christopher Mark Comer and Ashley Taggart (2021) contend that posthumanism is a transitional era after the disastrous apocalyptic incidents where survived people begin a new life again. Notwithstanding, their survival is accompanied with mixed feelings of grief and lovely happiness as they get into new post-human life: "the mysterious nature of deep emotions (grief, love), agency and determinism, the mind/brain divide, and even engages with trans- and posthumanism, topping it all off with an apocalyptic vision of the 'end of narrative'" (p.229). Therefore, Comer Ashley Taggart (2021) emphasises the apocalyptic nature of posthumanism. Yet, they (2021) argue that it emerges out of the survival experience that enabled the characters to live in a new transitional condition. In essence, post-human life, in post-apocalyptic narratives, underpins the nature of postmodern life. Postmodern life actually began after the Great World Wars. As such, it began after massive military destruction. Similarly, post-human life comes out of apocalyptic calamity. Maria-Sabina Draga Alexandru and Dragos Manea (2021) tackle posthumanism from a postmodern perspective. They (2021) claim that apocalyptic literary narratives are set "in a post-human light, looking at its engagement with the postmodern paradigm of diversity and with the ethical concerns" (p.163). In the light of this claim, posthumanism is a new life, a new beginning, and new hope. To explore McCarthy's perception of a new humanism, I prefer to describe this posthumanism interchangeably with "new humanism" due to two reasons. First, the characters could find new hope and pessimism after the end of the apocalyptic earthquake. Second, new humanism embodies posthumanism by revealing the sense of belonging, which is described in the boy's decision to live with the new family he found in the woods.

As for hope and pessimism, the boy and his father find a suitable shelter in the vast woods. They could have comfortable rest. In the beginning, they were almost hopeless and despondent. They did not know or predict their future as they might die like others. However, they eat and rest in the woods. Then, hope springs when the boy tries to find a path for his survival. He contemplates the coast and the other natural places in the vicinity of the woods. This hope might bring him a better life and a new beginning after the bitter journey: "they ate well, but they were still a long way from the coast. He knew that he was placing hopes where he'd say no reason to. He hoped it would be brighter where for all he knew the world grew darker daily" (p.113). Consequently, the boy's hope incarnates this new beginning for a better future. Here, it is worth mentioning that the apocalyptic events previously made the boy and his father devoid of any hope. They could not think of anything else except their survival and life. For this reason, they immediately left their destroyed places for the sake of refuge and good living. The first place they find is the serene woods. As argued earlier, arriving at the woods is the beginning of the boy's and his father's post-human life, which is paradigmatically the literary connotation of my argumentation of the new humanism.

The post-human life, in fact, depends on the theme of survival. That is, the characters could not be blessed with post-human or new human life unless they undergo the complex experience. Here, the post-human notion indicates the complicated conditions caused by the apocalyptic incidents. In this respect, Axel Fliethmann and Christiane Weller (2021) claim that the apocalyptic narratives have a great degree of apocalyptic complications that ultimately lead to post-human life; Fliethmann and Weller (2021) argue that apocalyptic narrative comprises descriptions "offering an examination of the complications of survival for the living and the once-dead post-human subjects" (p.264). Furthermore, authors of apocalyptic narratives have a sufficient capacity for literary vision. To explain, the experimental style of authors must have a distinctive vision that makes their works palpable. In this way, the experimental nature of post-human fiction originates in the destructive apocalypse. The fictional characters, or the literary embodiment of human beings, strenuously seek their survival to be safe from apocalyptic destruction; this is true to Sherryl Vint's argument (2021) that "this vision aligns with affirmative posthumanism ... a sense of the vibrancy of living"; and this living is the starting point of post-human civilisation "evoking the apocalyptic destruction that allows only a narrow version of chosen humanity to survive" (p.88). Vint's (2021) looks into posthumanism through the lens of survival. This means that survival is the key to the new transitional beginning after the apocalyptic events. Here, my concern is to relate the sense of posthumanism to new humanism and its relative postmodern civilisation. In this regard, the sense of belonging is the vital connection point between the apocalyptic events and new humanism because the boy finds a new family in the woods after his father's death. This is because he could find unprecedented comfort and rest, especially after the apocalyptic earthquake and its devastating aftermath.

The boy, therefore, develops a sense of belonging to the new family he finds in the woods. Ne humanism, accordingly, immediately begins with the boy's acceptance of living together with the family in the woods. McCarthy does not depict the boy in a nonreluctant state. He joins them; she loses everything, including his father. Here, McCarthy's experimental narrative style encompasses the themes of survival via the boy's sense of belonging to the family, which is new humanism per se. McCarthy's cyclical narrative style enables him to use his narrator to tell the events through the boy's flashback when he first met the family and its head. The head of the family, who is mentioned as the man in the plot, gives the boy a map by which they can find a suitable place for their new life: "the boy nodded. He sat looking at the map. The man watched him. He thought he knew what that was about. He'd pored over maps as a child, keeping one finger on the town where he lived just as he would look up his family in the phone directory, among others, everything in its place; he was justified in the world. Come on, he said. We should go" (p.97). The boy goes with the 
family, and they seem to leave the woods for a new life. McCarthy's narrative cyclical experimentation denotes the current state of postmodern civilisation that had been going through a transitional phase. After the Great World Wars, it got rid of its negative life and entered a new era with hope guided by socio-cultural prosperity. By the same token, the boy begins a new life motivated by hope and aspiration; and the map is a symbolic guide for his new life, which just resembles postmodern civilisation. Thus, McCarthy's experimentally portrays this civilisation by dint of new humanism.

\section{Conclusion}

This study has examined experimental narrative structure as an embodiment of new humanism in McCarthy's The Road. The study has focused on literary experimentation as a key factor in revealing McCarthy's depiction of new humanism as an alternative to destructive natural catastrophe exemplifying the turbulent postmodern life. It has also discussed the narrative components of the novels to demonstrate how McCarthy uses avant-garde narrative style to pinpoint his portrayal of post-apocalyptic events that harm and destroy human beings' lives in the postmodern world. For this reason, the study has conducted a qualitative study of the novel's narrative elements. These elements have been specifically the characters, the spatial setting, and the narrative descriptions that are vital for exploring the essence of a postmodern new humanism, which is rarely tackled in previous studies. The study has traced McCarthy's adroit use of the characters and their traits depicted in the plot.

One of the study's major findings is, consequently, literary experimentation. In this respect, the study has identified McCarthy's literary experimentation with the characters, spatial settings, and narrative descriptions. The study has revealed his gradual portrayal of the transformation of the characters. To clarify, the characters live in good and stable conditions that are interrupted by apocalyptic catastrophe; such catastrophe is referred to as an earthquake in the plot. As a result, the characters' transformation occurs when they leave for other safer places to seek refuge from further catastrophes after the first earthquake. The discussion of the characters' transformation has been enhanced by discussing the scenes of deteriorating environmental places that are negatively affected by apocalyptic events. The literary experimentation with this radical change has been pinpointed by shedding light on how McCarthy employs artistic language in describing the characters' state, especially the boy and his father, without mentioning their names. Therefore, the culmination of their change occurs when the boy finds a new life with a family living in the woods.

The description of the novel's spatial setting and the theme of survival is another definitive study finding. It has been found that the spatial setting is an authentic and viable literary vehicle used by McCarthy to project his own warning against the environmental deterioration in the contemporary postmodern world. Just so, he provides precise narrative details about the places representing the novel's spatial setting; these details are merely conscious narrative clues of how nature changes by the effect of an apocalyptic incident, which is hardly tackled in the existing scholarship on the novel. Accordingly, the spatial setting has been discussed to reveal the mass destruction leading to a post-apocalyptic life. The last contribution of the study has been the theme of survival. In essence, the theme of survival has been elaborated through the boy's sense of belonging to the family that he found in the woods. That is, his new living and belonging to the new family exemplifies McCarthy's implied notion concerning the world's contemporary transformation to new humanism incanted in postmodern civilisation. Thus, new humanism has been explored as a literary manifestation of the continual transformation of postmodern advancement.

Funding: This research received no external funding.

Conflicts of Interest: The authors declare no conflict of interest. 


\section{References}

[1] Bacevich, A. (2021). After the apocalypse: America's role in a world transformed. New York: Macmillan.

[3] Black, J. (2021). The Broadview Anthology of British literature. Peterborough, Ontario, Canada: Broadview Press.

[4] Blasi, G. (2014). Reading allegory and nature in Cormac McCarthy's The Road: Towards a non-anthropocentric vision of the language of nature. Arcadia, 49(1), 89-102.

[5] Bueno, C. (2019). Trauma and existentialism in Cormac McCarthy's The Road. Nordic Journal of English Studies, 18(1), 72-94.

[7] Caracciolo, M., Marcussen, M., and Rodriguez, D. (2022). Narrating nonhuman spaces: Form, story, and experience beyond anthropocentrism. New York: Routledge, Taylor \& Francis Group.

[9] Comer, C. M., and Taggart, A. (2021). Brain, Mind and the narrative imagination. London: London Bloomsbury Academic.

[13] Dedinova, T., Laszkiewicz, W., and Borowska-Szerszun, S. (2021). Images of the Anthropocene in speculative fiction. Narrating the future. Lexington: Lexington Books.

[14] Draga, A. M.-S., and Manea, D. (2021). Religious narratives in contemporary culture: Between cultural memory and transmediality. Leiden; Boston: Brill.

[15] Fliethmann, A., and Weller, C. (2021). Anatomy of the medical image: Knowledge production and transfiguration from the renaissance to today. Leiden; Boston: Brill.

[17] Kimak, M. (2019). See the child: Representations of childhood in Blood Meridian and The Road by Cormac McCarthy. East-West Cultural Passage, 10(2478), 29-38.

[19] Kundu, T., and Sarkar, S. (2021). The Post-human Imagination: Literature at the Edge of the Human. Newcastle upon Tyne: Cambridge Scholars Publishing.

[22] Levick, A. (2021). Memory and the built environment in 20th-century American literature: A reading and analysis of spatial forms. London: Bloomsbury Academic.

[25] McCarthy, C. (2016). The road. New York: Alfred A. Knopf, Inc.

[27] Payne, M. (2021). Flowers of time: On post-apocalyptic fiction. Princeton: Princeton University Press.

[29] Radford, A., and Van, H. H. (2021). British experimental women's fiction, 1945-1975: Slipping through the labels. Cham: Palgrave Macmillan.

[31] Vint, S. (2021). Biopolitical futures in twenty-first-century speculative fiction. Cambridge, United Kingdom; New York, NY: Cambridge University Press.

[34] Westfahl, G. (2021). Science fiction literature through history: An encyclopedia. Santa Barbara, California: Greenwood. 